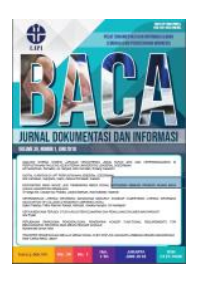

\title{
SURVEI PENGGUNAAN MEDIA SOSIAL DI KALANGAN MAHASISWA KOTA PADANG MENGGUNAKAN TEORI USES AND GRATIFICATIONS
}

\author{
Andi Saputra \\ UPT Perpustakaan Universitas Andalas \\ Korespondensi: andisptra@gmail.com \\ Diajukan: 31-01-2019; Direview: 14-03-2019; Diterima: 27-05-2018; Direvisi: 12-09-2019
}

\begin{abstract}
This research utilized theory uses and gratifications for discussing students' behavior in taking advantages of social media. Respondents came from 3 public universities in the city of Padang. The data collection method was done by distributing questionnaires and interviews, then, the data analyzed statistically. The results concluded that $97 \%$ of students claimed as social media active users. Based on the type of the application, the messenger/ chat app. was more preferable then the social networks. WhatsApp is the most application used. As many as $96 \%$ of respondents claimed using it. Whereas Facebook, the most preferable application uses throughout the world, is only used by $36 \%$ of respondents. A large number of WhatsApp users is in line with their goals and benefits use this content. The majority (87\%) of respondents use social media as a tool of communication, in addition to information retrieval, and social interaction.
\end{abstract}

\begin{abstract}
ABSTRAK
Penelitian ini memanfaatkan teori uses and gratifications untuk membahas tentang perilaku mahasiswa dalam memanfaatkan media sosial. Responden berasal dari 3 perguruan tinggi negeri di Kota Padang. Metode pengumpulan data dilakukan dengan membagikan kuesioner dan wawancara. Data dianalisis secara statistik. Hasil penelitian 97\% mahasiswa mengaku sebagai pengguna aktif media sosial. Berdasarkan jenis aplikasinya, messenger/chat app lebih diminati dibandingkan dengan social network. WhatsApp menjadi aplikasi yang paling banyak digunakan. Sebanyak $96 \%$ responden mengaku menggunakannya. Sedangkan Facebook, aplikasi yang selama ini paling banyak digunakan di seluruh dunia, hanya digunakan oleh 36\% responden. Banyaknya jumlah pengguna WhatsApp sejalan dengan tujuan dan manfaat menggunakan konten ini. Sebagian besar responden (87\%) memanfaatkan media sosial sebagai alat komunikasi, disamping untuk pencarian informasi, serta interaksi sosial.
\end{abstract}

Keywords: Social media; Communication; User; Gratifications theory; Academic library

\section{PENDAHULUAN}

Parker (2003) \& Solis (2008) mengatakan bahwa media sosial sebagai sarana untuk berinteraksi orang-orang satu sama lain dengan cara menciptakan, berbagi, serta bertukar informasi dan gagasan melalui kata-kata, gambar, dan video dalam sebuah jaringan dan komunitas virtual. We are Social (2018) membaginya ke dalam dua kelompok, yaitu: social network dan messenger/chat app/voip. Social network atau jejaring pertemanan, merupakan sebuah bentuk layanan internet yang menjadi wadah komunitas online, yaitu orang-orang yang memiliki kesamaan aktivitas, ketertarikan atau minat pada bidang tertentu, atau dari latar balakang/komunitas yang sama, seperti Youtube, Facebook, Instagram, Twitter, dsb. Messenger/chat app merupakan sarana untuk saling berkirim pesan antar pengguna, baik itu berupa teks, audio, gambar maupun video, misalnya FB Messenger, WhatsApp, Wechat, Skype, BBM, Telegram, dsb. Facebook merupakan platfom dengan pertumbuhan pengguna 
terbesar di seluruh dunia, dengan rata-rata pertumbuhan 24\% pertahun, sedangkan untuk kategori messenger/app chat WhatsApp dan Instagram yang paling banyak digunakan.

Media sosial cukup relevan jika dikaitkan dengan teori uses and gratifications, yang berasal dari sumber-sumber literasi ilmu komunikasi. Pendekatan ini pada awalnya dijabarkan oleh Katz (1959). Tujuan kajian uses and gratifications adalah untuk mencari tahu alasan seseorang menggunakan atau menghindari sebuah media massa, manfaat penggunaan media massa; dan hal apa saja yang mereka sukai di antara berbagai pilihan dari media massa. Severin \& Tankard (2009); Blumler (1979) mengkategorikan kebutuhan dan gratifikasi pengguna media massa menjadi empat kategori, yaitu pengalihan, hubungan personal, identitas pribadi/psikologi individu, dan pengawasan.

Pendekatan teori uses and gratifications menganggap bahwa pengguna bersikap aktif dalam memenuhi kebutuhannya terhadap media massa. Kubey \& Csikszentmihalyi (1990) dalam Severin \& Tankard (2009), mengatakan bahwa pengguna cenderung pasif, santai, dan tidak membutuhkan konsentrasi. Kebutuhan pengguna diciptakan oleh media atau merupakan sebuah reasionalitas dari manfaat media. Pada waktu itu, kajian pemanfaatan uses and gratifications terbatas pada kajian media-media konvensional, seperti koran dan televisi (Elliott \& Rosenberg, 1987; Babrow, 1987; Bantz, 1982).

Munculnya media sosial yang melibatkan peran aktif dari pengguna sepertinya bisa menjawab kritikan dari para ahli terhadap keberadaan teori uses and gratifications. Penelitian ini mencoba untuk menggali pemanfaatan media sosial di kalangan mahasiswa perguruan tinggi menggunakan teori uses and gratifications. Konsep manfaat dan gratifikasi penelitian ini merupakan pengembangan dari 10 manfaat dan gratifikasi yang digunakan dalam penelitian (Whiting \& Williams, 2013). Hal yang dikaji mencakup informasi tentang media sosial apa yang paling sering mereka gunakan; bagaimana dan kapan mereka menggunakannya; berapa lama waktu yang mereka gunakan; tujuan dan motivasi mereka menggunakannya.

\section{LANDASAN TEORI}

Kent (2013) mendefenisikan media sosial sebagai segala bentuk media komunikasi interaktif yang memungkinkan terjadinya interaksi dua arah dan umpan balik. Maraknya perkembangan media sosial telah menarik minat orang untuk melakukan kajian dari berbagai perspektif yang berbeda. Aji (2014); Saravanakumar \& Lakshmi (2012); Reuben (2008) meneliti tentang pemanfaatan media sosial di dunia marketing. Drestya (2013) meneliti tentang motif mahasiswa menggunakan media sosial Path di Surabaya.

Reuben (2008) mengatakan bahwa media sosial merupakan potensi kekuatan dan sebagai bagian dari komponen pemasaran dan penyebaran informasi secara menyeluruh di perguruan tinggi. Menurut Asosiasi Pengguna Jasa Internet Indonesia/APJII (2018), pengguna internet di Indonesia berasal dari kelompok usia muda, umur 19 - 34 tahun dengan jumlah sekitar $49,52 \%$ dari total pengguna, dan mahasiswa merupakan populasi terbesar dalam rentang usia tersebut.

Lariscy, Tinkham, \& Sweetser (2011) mengatakan bahwa teori uses and gratifications yang berakar pada literatur komunikasi, dapat menjadi bagian integral dari pengembangan skala dan instrumen pengukuran yang lebih baik untuk penelitian media sosial. Prinsipnya bahwa individu memperoleh kepuasan tertinggi dalam memanfaatkan media sosial. Hal tersebut didukung oleh beberapa penelitian tentang teori uses and gratifications untuk pemanfaatan media sosial, diantaranya penelitian pada WeChat (Wang \& Gan, 2015; Gan \& 
Li, 2018); Facebook (Krause, North, \& Heritage, 2014); Twitter (Coursaris et al., 2013), atau media sosial lain (Dolan et al., 2016; Whiting \& Williams, 2013).

\section{METODE}

Penelitian ini mengeksplorasi perilaku mahasiswa Kota Padang dalam menggunakan media social berdasarkan teori uses and gratifications. Responden penelitian berasal dari tiga perguruan tinggi negeri di Kota Padang, yaitu Universitas Andalas (UNAND), Universitas Negeri Padang (UNP), dan Universitas Islam Negeri Imam Bonjol (UIN-IB). Jumlah responden sebanyak 99 mahasiswa diambil secara merata dari ketiga perguruan tinggi tersebut. Angka tersebut diperoleh dari nilai maksimum sampel hasil perhitungan menggunakan Rumus Slovin, dengan toleransi kesalahan (margin error) 10\%. Pemilihan sampel menggunakan metode random sampling, sampel dipilih secara acak tanpa membedakan fakultas, jenjang studi, dan tahun masuk, serta jenis kelamin. Tidak ada perlakuan khusus terhadap responden. Pengumpulan data dilakukan dengan membagikan angket dan wawancara. Daftar pertanyaan yang diajukan terdiri dari: (1) keaktifan pengguna internet dan media social; (2) platfom media sosial yang saat ini digunakan dan yang paling sering digunakan; (3) tujuan dan motivasi pengguna menggunakan media social; (4) perangkat akses media sosial yang digunakan; (5) alokasi waktu yang digunakan untuk mengakses media sosial.

Dalam memahami perilaku responden, penulis menggunakan pendekatan uses and gratifications. Model yang digunakan merupakan pengembangan dari teori yang digunakan oleh (Whiting \& Williams, 2013) memodifikasi sepuluh uses and gratifications penggunaan media sosial, yaitu dengan menambahkan kriteria bisnis online. Kriteria ini penting untuk ditambahkan, karena saat ini keberadaan media sosial tidak hanya sebatas sarana komunikasi dan hiburan belaka, akan tetapi sudah jauh berkembang, salah satunya adalah menjadi sarana promosi dan transaksi bisnis. Selain itu, ditambahkan kategori untuk menyampaikan opini/update status. Kategori ini dianggap relevan jika dijadikan sebagai salah satu motivasi dari pengguna media sosial, terutama pengguna social network, seperti Facebook, Youtube, Instagram, dan Twitter. Perbedaan lainnya adalah pada kategori hiburan. Kategori hiburan, relaksasi, dan kenyamanan/ kesenangan menurut Whiting \& Williams (2013) digabungkan menjadi satu kategori agar responden mudah dalam memahami pertanyaan dalam pengumpulan data.

\section{HASIL DAN PEMBAHASAN}

\subsection{Hasil}

Berdasarkan hasil pengolahan data dari 99 responden diketahui ada 55 responden perempuan $(55,56 \%)$ dan 44 responden laki-laki $(44,44 \%)$ yang mengisi kuesioner penelitian (Tabel 1).

Tabel 1. Informasi Demografi Responden ( $\mathrm{N}=99)$

\begin{tabular}{|c|c|c|c|}
\hline Kategori & Item & Jumlah & $\%$ \\
\hline \multirow[t]{2}{*}{ Gender } & Laki-laki & 44 & 44,44 \\
\hline & Perempuan & 55 & 55,56 \\
\hline \multirow[t]{3}{*}{ Jenjang studi } & D3 & 24 & 24 \\
\hline & $\mathrm{S} 1$ & 73 & 73 \\
\hline & S2 & 3 & 3 \\
\hline Pengguna aktif internet & $\mathrm{Ya}$ & 97 & 97,98 \\
\hline
\end{tabular}




\begin{tabular}{|l|c|c|c|}
\hline & Tidak & 2 & 2,02 \\
\hline \multirow{2}{*}{$\begin{array}{l}\text { Pengguna aktif media } \\
\text { sosial }\end{array}$} & Ya & 94 & 94,95 \\
\cline { 2 - 4 } & Tidak & 5 & 5,05 \\
\hline
\end{tabular}

Jumlah responden yang memanfaatkan media sosial dijelaskan sebagai berikut.

\section{a. Pengguna Internet dan Media Sosial}

Penelitian sebelumnya melaporkan bahwa $89,7 \%$ pengguna internet di Indonesia adalah mahasiswa, dan $97 \%$ dari pengguna internet telah mengakses konten media sosial (APJII, 2018). Sedangkan dalam penelitian ini, 98\% responden mengaku sebagai pengguna internet aktif, 97\% menyatakan aktif menggunakan media sosial. Terkait dengan perangkat yang mereka gunakan untuk mengakses media sosial, hasilnya bahwa smartphone saat ini menjadi perangkat yang paling banyak digunakan oleh mahasiswa untuk mengakses media sosial (85\%) dan 15\% menjawab menggunakan media sosial menggunakan smartphone dan laptop.

\section{b. Penggunaan Platform Media Sosial}

Platform media sosial yang digunakan dapat dilihat pada daftar platform laporan hasil survei We are Social (2018) dan laporan survei APJII (2018). Penilaiannya berdasarkan pada jenis platform yang saat ini sedang digunakan dan yang paling sering digunakan. Sebagian besar pengguna memanfaatkan lebih dari satu jenis platform media sosial dan ada salah satu yang menjadi favorit atau yang paling sering digunakan (Gambar 1).

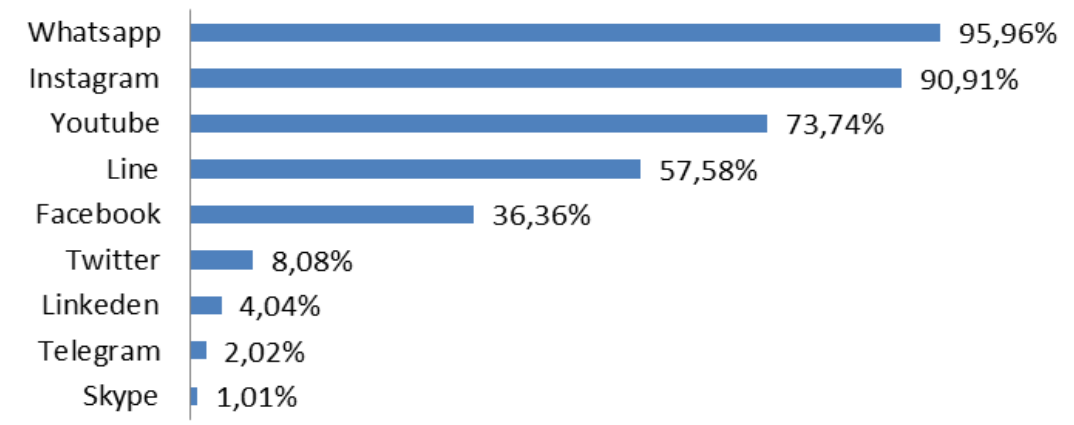

Gambar 1. Platform media sosial yang digunakan responden

Dari 23 jenis platform yang ditawarkan, hanya 9 platform media sosial yang dipilih oleh responden. Sebagian besar mahasiswa menggunakan WhatsApp, jumlahnya mencapai 95,96\% responden. Selanjutnya 90,91\% responden menggunakan Instagram, dan 73,74\% responden menggunakan Youtube. Sedangkan pengguna Facebook sebanyak 36,36\% responden dan Line sebanyak 57,58\% responden. Kemudian diikuti oleh pengguna Twitter, Telegram, Linkedin, dan Skype. Hal tersebut dapat dilihat pada Gambar 2. 


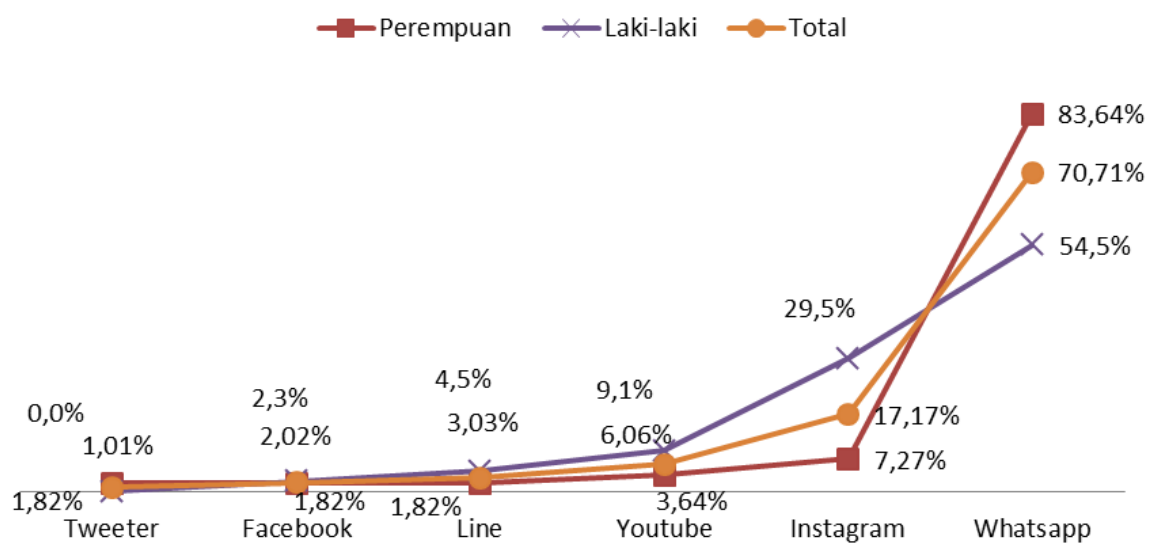

Gambar 2. Platform media sosial yang digunakan berdasarkan gender

Berdasarkan Gambar 2 ada empat platform dipilih responden sebagai aplikasi yang sering digunakan, yaitu WhatsApp (70,71\%), Instagram (17,17\%), Line (6\%), dan Facebook (2\%). Dilihat berdasarkan jenis kelamin pengguna, WhatsApp paling diminati oleh pengguna perempuan $(83,64 \%)$ dan selebihnya pengguna laki-laki $(54,5 \%)$. Pengguna laki-laki lebih dominan menggunakan Instagram (29,5\%) jika dibandingkan dengan perempuan $(7,27 \%)$. Begitu halnya dengan pengguna Youtube, pengguna laki-laki $(9,1 \%)$ lebih banyak jika dibandingkan dengan pengguna perempuan $(3,64 \%)$.

\section{c. Tujuan penggunaan media sosial}

Teori uses and gratifications diterapkan dalam pemanfaatan media sosial oleh mahasiswa UNAND, UNP, dan UIN IB. Mengacu pada tujuh kategori yang dikatakan Whiting \& Williams (2013), yaitu: (1) alat komunikasi (telepon/sms/chatting); (2) mencari informasi; (3) interaksi sosial/pertemanan; (4) bisnis online; (5) menyampaikan opini/update status (posting foto/video/informasi); (6) hiburan/relaksasi (mendegarkan musik/menonton video); (7) mengisi waktu luang, tujuan mahasiswa mengguna media sosial dapat dilihat pada Gambar 3.

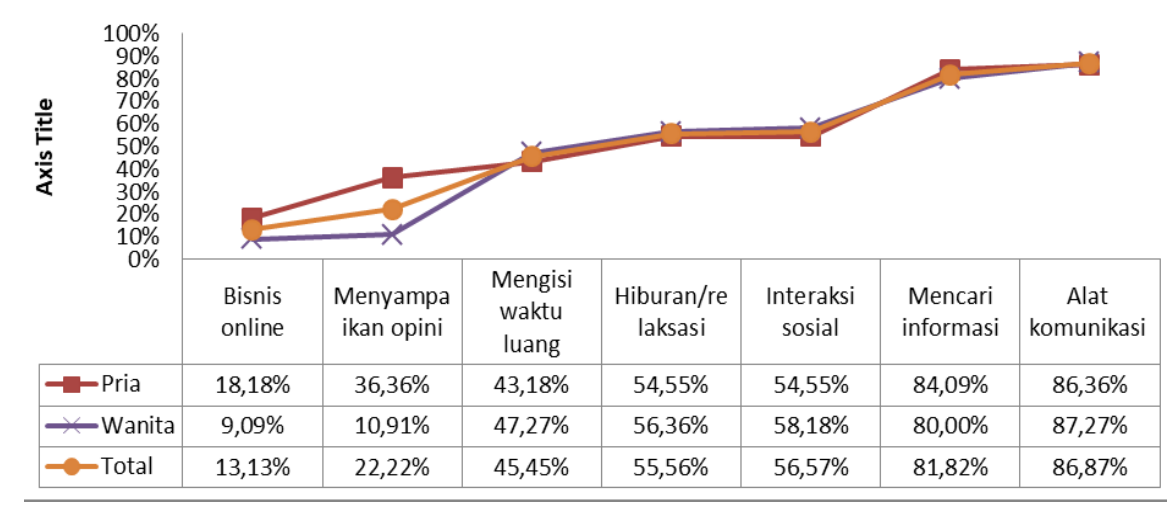

Gambar 3. Uses and Gratifications mahasiswa menggunakan media sosial

Berdasarkan Gambar 3, terlihat bahwa sebagian besar mahasiswa memanfaatkan media sosial sebagai alat komunikasi $(86,87 \%)$. Kemudian diikuti mencari informasi 
$(81,82 \%)$, interaksi sosial $(56,57 \%)$, hiburan/relaksasi $(55,56 \%)$, update status/penyampaian opini (22,22\%), mengisi waktu luang $(45,45 \%)$, dan bisnis online $(13,13 \%)$. Tidak ada perbedaan signifikan antara motif laki-laki dan perempuan menggunakan media sosial, kecuali untuk kategori menyampaikan opini dan bisnis online. Pengguna laki-laki lebih dominan dalam kategori tersebut jika dibandingkan dengan perempuan. Responden yang memilih alat komunikasi, sebagian besar menggunakan WhatsApp dan Line -karena ada kesamaan platform dengan rekan atau relasi yang sering dihubungi. Sedangkan responden yang memilih interaksi sosial dan update status, serta hiburan/relaksasi mengaku menggunakan Instagram dan Facebook. Responden yang memilih WhatsApp mengatakan bahwa selain murah digunakan untuk berkomunikasi, aplikasi ini juga mudah digunakan dan terbebas dari iklan.

\section{d. Pemanfaatan Waktu Akses Media Sosial}

Ada tiga aspek terkait waktu akses media sosial, yaitu alokasi. jadwal, dan durasi waktu (Tabel 2) yang digunakan dalam satu hari.

Tabel 2. Analisis Perilaku Responden Berdasarkan Waktu

\begin{tabular}{|c|c|c|c|c|c|c|c|c|c|c|}
\hline \multirow{2}{*}{ JK } & Alokasi Waktu & \multicolumn{4}{|c|}{ Waktu Akses } & \multicolumn{4}{c|}{ Durasi Waktu } \\
\cline { 2 - 11 } & Ya & Tidak & Pagi & Siang & Sore & Malam & $\begin{array}{c}\mathbf{1 - 3} \\
\text { Jam }\end{array}$ & $\begin{array}{c}\mathbf{4 - 6} \\
\text { Jam }\end{array}$ & $\begin{array}{c}\mathbf{7 - 1 2} \\
\text { jam }\end{array}$ & $\begin{array}{c}>12 \\
\text { Jam }\end{array}$ \\
\hline L & $18,18 \%$ & $81,82 \%$ & $11,11 \%$ & $11,11 \%$ & $11,11 \%$ & $66,67 \%$ & $40,91 \%$ & $34,09 \%$ & $18,18 \%$ & $6,82 \%$ \\
\hline P & $20,00 \%$ & $80 \%$ & $10,00 \%$ & $30,00 \%$ & $10,00 \%$ & $50,00 \%$ & $41,82 \%$ & $34,55 \%$ & $12,73 \%$ & $10,91 \%$ \\
\hline Total & $\mathbf{1 9 , 1 9 \%}$ & $\mathbf{8 0 , 8 1 \%}$ & $\mathbf{1 0 , 5 3 \%}$ & $\mathbf{2 1 , 0 5 \%}$ & $\mathbf{1 0 , 5 3 \%}$ & $\mathbf{5 7 , 8 9 \%}$ & $\mathbf{4 1 , 4 1 \%}$ & $\mathbf{3 4 , 3 4 \%}$ & $\mathbf{1 5 , 1 5 \%}$ & $\mathbf{9 , 0 9 \%}$ \\
\hline
\end{tabular}

Berdasarkan Tabel 2, terlihat bahwa ada $17 \%$ responden yang mengalokasikan waktu

khusus untuk mengakses konten media sosial. Sisanya menjawab 'Tidak', mereka mengakses konten media sosial kapan saja yang mereka inginkan. Bagi responden yang menjawab 'Ya', diajukan pertanyaan berikutnya yang terkait dengan alokasi waktu akses konten media sosial. Sebagian besar responden cenderung memilih mengakses konten media sosial pada malam hari (75\%), sedangkan responden yang lain memilih siang hari $(16,67 \%)$ dan pagi hari $(8,33 \%)$. Kemudian terkait dengan durasi waktu rata-rata dalam mengakses konten media sosial setiap harinya, diketahui bahwa sebagian besar mahasiswa menghabiskan waktu rata-rata 1 - 3 jam perhari (39,39\%); 4 - 6 jam perhari $(32,32 \%)$; 7 12 jam perhari (20,20\%); dan lebih dari 12 jam sehari $(4,04 \%)$.

\subsection{Pembahasan}

Sebagaimana dijelaskan Tabel 1 bahwa hampir semua responden merupakan pengguna aktif internet dan media sosial. Hal tersebut tidak berbeda jauh dengan laporan APJII (2018) bahwa pengguna internet di Indonesia meningkat tajam dalam kurun waktu tiga tahun terakhir, dari $34,9 \%$ pada tahun 2014 menjadi 54,68\% pada tahun 2018; dan laporan We are Social (2018) bahwa layanan internet yang paling banyak diakses yaitu media sosial (89,35\%). Semua responden mengaku menggunakan smartphone. Apabila dibandingkan dengan laporan APJII (2018), penggunaan handphone untuk mengakses internet sedikit lebih rendah, yaitu $83,44 \%$. Hal ini menunjukkan bahwa penggunaan handphone di kalangan mahasiswa persentasenya di atas rata-rata kelompok usia lainnya.

WhatsApp merupakan konten yang paling banyak digunakan oleh mahasiswa (Gambar 1 dan Gambar 2). Sebanyak 95,96\% mahasiswa mengaku sebagai pengguna WhatsApp. Hasil 
ini berbeda dengan laporan We are Social (2018) yang masih menempatkan Facebook sebagai platform paling diminati oleh para masyarakat global (2,167 Milyar pengguna), di mana WhatsApp digunakan oleh 1,3 Milyar pengguna. Sementara itu, menurut hasil penelitian ini (Gambar 3) pengguna Facebook hanya 36,36\%, di bawah Instagram, Youtube, dan Line. Hal yang menarik dari platform media sosial yang digunakan di kalangan mahasiswa, aplikasi Line tidak termasuk dalam 6 besar kategori media sosial yang paling banyak (menurut Laporan APJII 2018). Penelitian ini menyatakan bahwa 57,58\% responden mengaku mengunakannya, jumlahnya sedikit di bawah Instagram (86\%) dan Youtube $(73,74 \%)$, yang telah melampaui jumlah pengguna Facebook.

Dilihat berdasarkan jenis kelamin diketahui bahwa tidak ada perbedaan signifikan dalam penggunaan media sosial antara laki-laki dengan perempuan. Sedangkan untuk platform yang paling diminati, ada sedikit perbedaan antara laki-laki dan perempuan. Perempuan lebih dominan menggunakan WhatsApp jika dibandingkan dengan laki-laki, sedangkan laki-laki lebih dominan dalam menggunakan Instagram dan Youtube (Gambar 2). Mahasiswa menggunakan media sosial untuk alat komunikasi (94\%), mencari informasi (84\%), dan sarana interaksi sosial/pertemanan (71\%) (Gambar 3). Hal ini sedikit berbeda dengan penelitian Whiting \& Williams (2013), yang menggunakan metode uses and grafitations, yang mengatakan bahwa tujuan utama pengguna media sosial adalah untuk interaksi sosial (88\%), mencari informasi (80\%), dan mengisi waktu luang (76\%).

Dilihat berdasarkan kategori pemanfaatannya, WhatsApp dan Line digunakan sebagai sarana komunikasi, baik dalam bentuk pesan maupun suara. Facebook digunakan untuk interaksi sosial/ajang pertemanan, selain sebagai tempat pencarian informasi. Sedangkan Youtube dan Instagram banyak digunakan untuk hiburan dan tempat mencari informasi. Pengguna perempuan lebih banyak memanfaatkan WhatsApp sebagai media komunikasi sedangkan laki-laki lebih dominan menggunakan Instragram dan Youtube untuk media komunikasi dan sarana hiburan. Adanya penambahan kategori dalam menyampaikan opini atau update status dan bisnis online ke dalam teori uses and gratifications. Kategori cukup banyak dipilih oleh responden, di mana untuk menyampaikan opini (38\%) dan bisnis online (11\%) (Gambar 5).

Dilihat berdasarkan waktu penggunaannya, sebagian besar responden (81\%) tidak mengalokasikan waktu/membuat jadwal khusus untuk mengakses media sosial. Kalaupun ada mereka lebih memilih waktu pada malam untuk mengakses media sosial (Tabel 2). Sebagian besar waktu yang digunakan untuk mengakses media sosial antara $1-6$ jam sehari (Gambar 6). Hal ini sesuai dengan durasi penggunaan internet di Indonesia (APJII, 2018), dimana $73,5 \%$ pengguna internet menghabiskan waktu $1-7$ jam per hari; dan laporan We are Social (2018), menyatakan bahwa rata-rata pengguna media sosial di Indonesia menghabiskan waktu selama 3 jam 23 menit. Tidak ada perbedaan signifikan antara laki-laki dan perempuan. Terkait alokasi waktu akses, mahasiswa memanfaatkannya dalam waktu sehari. Persentase antara laki-laki dan perempuan tidak memiliki perbedaan yang signifikan (Tabel 2).

\section{KESIMPULAN}

Berdasarkan hasil dan pembahasan di atas dapat disimpulkan bahwa sebagian besar responden (mahasiswa) merupakan pengguna aktif media sosial. Media sosial sudah menjadi bagian keseharian mahasiswa. Mereka memanfaatkan media sosial tidak dalam waktu khusus dengan rata-rata durasi penggunaan selama $1-6$ jam sehari. Dari segi waktu, tidak ada perbedaan signifikan antara pengguna laki-laki dengan perempuan. Ditemukan perbedaan 
jenis platform yang paling diminati di kalangan mahasiswa Kota Padang dibandingkan dengan pengguna media sosial secara global. Sebanyak mahasiswa menggunakan WhatsApp (95,96\%), Instagram (90,91\%), dan Youtube (73,74\%). Facebook merupakan platform media sosial yang paling banyak digunakan di seluruh dunia, namun hanya 36,36\% mahasiswa. Dari tujuh kategori uses and gratifications, sebagian besar responden (86\%) menjadikan media sosial sebagai media komunikasi, dibandingkan sebagai sarana pencarian informasi dan interaksi sosial. Dari aspek gender, pengguna perempuan lebih dominan menggunakan WhatsApp jika dibanding dengan pengguna laki-laki. 


\section{DAFTAR PUSTAKA}

Aji, Dewi Pratiwi Putri. 2014. "Penggunaan Media Sosial dalam Pemenangan Joko WidodoBasuki Tjahaha Purnama pada Pilkada DKI Jakarta 2012 (Studi Atas Marketing Politik di Facebook dan Twitter)". Di http://repository.uinjkt.ac.id/dspace/handle/123456789/24214 (akses 17 Januari 2019).

Asosiasi Pengguna Jasa Internet Indonesia/APJII. 2018. "Data Statistik Pengguna Internet Indonesia 2018".

Babrow, Austin S. 1987. Student Motives for Watching Soap Operas. Journal of Broadcasting \& Electronic Media 31 (3): 309-21. https://doi.org/10.1080/08838158709386666.

Bantz, Charles R. 1982. Exploring Uses and Gratifications: A Comparison of Reported Uses of Television and Reported Uses of Favorite Program Type. Communication Research 9 (3): 352-79. https://doi.org/10.1177/009365082009003002.

Blumler, Jay G. 1979. The Role of Theory in Uses and Gratifications Studies. Communication Research 6 (1): 9-36. https://doi.org/10.1177/009365027900600102.

Coursaris, Constantinos, Wietske Van Osch, Jieun Sung, \& Younghwa Yun. 2013. Disentangling Twitter's Adoption and Use (Dis) Continuance: A Theoretical and Empirical Amalgamation of Uses and Gratifications and Diffusion of Innovations. AIS Transactions on HumanComputer Interaction 5 (1): 57-83.

Dolan, Rebecca, Jodie Conduit, John Fahy, \& Steve Goodman. 2016. Social Media Engagement Behaviour: A Uses and Gratifications Perspective. Journal of Strategic Marketing 24 (3-4): 261-77. https://doi.org/10.1080/0965254X.2015.1095222.

Drestya, Dyane Aulia. 2013. Motif Menggunakan Sosial Media Path pada Mahasiswa di Surabaya. Jurnal Commmonline Departemen Komunikasi 3(3): 530-536.

Elliott, William R., \& William L. Rosenberg. 1987. The 1985 Philadelphia Newspaper Strike: A Uses and Gratifications Study. Journalism Quarterly 64 (4): 679-87. https://doi.org/10.1177/107769908706400401.

Gan, Chunmei, \& Hongxiu Li. 2018. Understanding the Effects of Gratifications on the Continuance Intention to Use WeChat in China: A Perspective on Uses and Gratifications. Computers in Human Behavior 78 (January): 306-15. https://doi.org/10.1016/j.chb.2017.10.003.

Kent, Michael L. 2013. Using Social Media Dialogically: Public Relations Role in Reviving Democracy. Public Relations Review 39 (4): 337-45. https://doi.org/10.1016/j.pubrev.2013.07.024.

Krause, Amanda E., Adrian C. North, \& Brody Heritage. 2014. The Uses and Gratifications of Using Facebook Music Listening Applications. Computers in Human Behavior 39 (October): 71-77. https://doi.org/10.1016/j.chb.2014.07.001.

Parker, S.P. 2003. McGraw-Hill Dictionary of Scientific and Technical Terms. McGraw-Hill Dictionary of Scientific and Technical Terms. McGraw-Hill Education. Di https://books.google.co.id/books?id=xOPzO5HVFfEC (akses 17 Januari 2019). 
Reuben, Rachel. 2008. The Use of Social Media in Higher Education for Marketing and Communications: A Guide for Professionals in Higher Education. Rachel Reuben Consulting, LLC (blog). August 19. Di https://rachelreuben.com/2008/08/19/social-mediauses-higher-education-marketing-communication/ (akses 17 Januari 2019).

Saravanakumar, M., \& T. Sugantha Lakshmi. 2012. Social Media Marketing. Life Science Journal 9 (4): 4444-4451.

Severin, W. J., \& J.W. Tankard, Jr. 2009. Teori Komunikasi, Sejarah, Metode, dan Terapan di Dalam Media Massa, 5th ed. Jakarta: Kencana.

Solis, Brian. 2008. Customer Service: The Art of Listening and Engagement Through Social Media.

Wang, Weijun, \& Chunmei Gan. 2015. Uses and Gratifications of Social Media: A Comparison of Microblog and WeChat. Journal of Systems and Information Technology 17 (4): 351-63. https://doi.org/10.1108/JSIT-06-2015-0052.

We are Social. 2017. "Digital in 2017: Global Overview". Di https://wearesocial.com/specialreports/digital-in-2017-global-overview (akses 17 Januari 2019).

We are Social. 2018. "Digital in 2018: Global Overview". Di https://wearesocial.com/specialreports/digital-in-2017-global-overview (akses 17 Januari 2019).

Weaver Lariscy, Ruthann, Spencer F. Tinkham, \& Kaye D. Sweetser. 2011. Kids These Days: Examining Differences in Political Uses and Gratifications, Internet Political Participation, Political Information Efficacy, and Cynicism on the Basis of Age. American Behavioral Scientist 55 (6): 749-64. https://doi.org/10.1177/0002764211398091.

Whiting, Anita \& David Williams. 2013. Why People Use Social Media: A Uses and Gratifications Approach. Qualitative Market Research: An International Journal 16 (4): 362-69. https://doi.org/10.1108/QMR-06-2013-0041. 